\title{
Anti-Elastase, Antioxidant, Total Phenolic and Total Flavonoid Content of Wuru Ketek (Myrica javanica Reinw. ex Bl.) from Tangkuban Perahu, West Java - Indonesia
}

\author{
Varda Arianti, Berna Elya*, Iskandarsyah
}

Varda Arianti, Berna Elya*, Iskandarsyah

Faculty of Pharmacy, Universitas Indonesia, Depok, 16424, West Java, INDONESIA.

\section{Correspondence}

\section{Berna Elya}

Faculty of Pharmacy, Universitas Indonesia, Depok, 16424, West Java, INDONESIA.

E-mail: berna.elya@farmasi.ui.ac.id History

- Submission Date: 22-12-2019;

- Review completed: 06-01-2020;

- Accepted Date: 16-01-2020.

DOI : 10.5530/pj.2020.12.46

Article Available online

http://www.phcogj.com/v12/i2

\section{Copyright}

(C) 2020 Phcogj.Com. This is an openaccess article distributed under the terms of the Creative Commons Attribution 4.0 International license.

\begin{abstract}
Introduction: The presence of elastase and ROS can cause skin aging, phenolic compounds and flavonoids can be used to inhibit elastase activity and as an antioxidant. Objective: This research aimed to evaluate the anti-elastase, antioxidant activities, TPC and TFC of extracts from Myrica javanica. Methods: In this study, the leaves, stems and fruit of Myrica javanica were macerated with $96 \%$ ethanol. The extracts obtained were analysed for anti-elastase and antioxidant activities. It was also evaluated for TPC and TFC. Result: IC50 anti-elastase on leaves extract (LE), stems extract (SE), and fruits extract (FE) respectively showed $64.71 \mathrm{ppm}$, 197.49 ppm, and no activity. The anti-elastase result of three extracts are lower if compared with Myricetine (9.54 ppm). SE showed highest DPPH and TPC value (IC50=16.36 $\mu \mathrm{g} / \mathrm{mL}$ $307.00 \mathrm{mgGAE} / \mathrm{g}$ dry weight) and LE showed highest FRAP and TFC value (421.68 Mol/gram; $15.80 \mathrm{mgQE} / \mathrm{g}$ dry weight). Conclusion: In summary, anti-elastase and antioxidant activity are influenced by differences in the content of compounds in the extract.

Key words: Anti-elastase, Antioxidant, TPC, TFC, Myrica javanica, Antiaging.
\end{abstract}

\section{INTRODUCTION}

Aging is a common process by which humans gradually lose skin elasticity and collagen fibers. Over the age of 20 years, aging manifestations appear as collagen content per unit area begins to decrease, there is a $1 \%$ reduction in collagen content per unit area of the skin each year. ${ }^{1}$ Skin aging is determined by a consolidation of intrinsic factors (genetics, cellular metabolism, and hormones) and extrinsic (continual light risk, pollution, ionizing radiation, chemicals, poisons). The subject of most of the research on antiaging and efforts for aesthetic-antiaging strategies related to the skin are the three main structural components of the dermis, namely collagen, elastin, and Glycosaminoglycans (GAGs). ${ }^{2}$

Skin elasticity and firmness are obtained in the presence of collagen and elastin in the skin layers. Collagen and elastin are broken down by the presence of MMP-1 and elastase enzymes which are increased due to excessive sun exposure. The absorbed UV light causes an increase in oxygen radical species (ROS) and induces oxidative stress. A high amount of ROS increases elastase activity. Expanded elastase enzyme activity triggers different diseases such as rheumatoid arthritis, cystic fibrosis, chronic respiratory diseases, psoriasis, deferred wound healing and premature skin aging with wrinkle formation. Therefore, antioxidants and anti-elastase can potentially be cosmetic in the fight against skin aging. ${ }^{3,4}$

Plants from the genus Myrica such as Myrica esculenta, Myrica faya, and Myrica gale have antioxidant activities because they contain secondary metabolites such as polyphenols (such as phenolic acids and flavonoids),, 5 and several research results show that polyphenol compounds and flavonoids have strong activity in inhibiting the activity of enzymes and antioxidants. ${ }^{8-10}$ Some compounds contained in the genus Myrica reported to have elastase inhibitory activity including myricetin, quersetin. ${ }^{11}$

Based on this, the Myrica javanica plant, which is also a plant from of the Myricaceae family might possible to have pharmacological activities that are no less as potential as the other Myrica genus, especially for its antiaging activities, as well as their use in making cosmetic preparations in the development of antiaging cosmetics.

The purpose of this study was to determine the potential anti-elastase and antioxidant of Myrica javanica and analysed the TPC and their TFC.

\section{MATERIAL AND METHODS}

\section{Reagents}

Elastase from porcine pancreas (Sigma, SLBV 9311) N-Succinyl-Ala-Ala-Ala-p-nitroanilide (SANA) (Sigma, SLBR 7591V), Folin Ciocalteau Reagent (FCR) (Sigma), Trizma Base (Sigma, T1503), 2,4,6-Tris(2-pyridyl)-s-triazine (TPTZ) (Sigma). Sodium carbonate, aluminium chloride, ethanol $96 \%$, methanol, ferric chloride hexahydrate, acetic acid, hydrochloride acid ( $\mathrm{HCl})$, dimethyl sulfoxide (DMSO) (Merck, Germany).

\section{Plant materials}

The leaves, stems, and fruit of the Myrica javanica plant were obtained from the Tangkuban Perahu

Cite this article: Arianti V, Elya B, Iskandarsyah. Anti-Elastase, Antioxidant, Total Phenolic and Total Flavonoid Content of Wuru Ketek (Myrica javanica Reinw. ex BI.) from Tangkuban Perahu, West Java - Indonesia. Pharmacog J. 2020;12(2):293-7. 
forest in the Bandung area, West Java. Plants are determined by the School of Life Science and Technology, Bandung Institute of Technology (ITB) (Approval No. 3911/I1.CO2.2/PL/2019).

\section{Extraction}

50 gram of Myrica javanica leaves, stems and fruit of each plant was extracted by 3 times maceration method using $96 \%$ ethanol $(500 \mathrm{ml})$, then stirred and allowed to stand for 24 hours. The extracts were concentrated with a rotary vacuum evaporator and dried over a water bath, stored in a closed container.

\section{Anti-elastase assay}

Anti-Elastase assay was determined according to the method of Wittenauer, et al. with modifications. ${ }^{12}$ Pre-incubation of $20 \mu \mathrm{l}$ extract sample in DMSO solution, $130 \mu \mathrm{L}$ buffered Tris- $\mathrm{HCl}$ pH 8.0 with PE (Porcine Elastase) $25 \mu \mathrm{l}$ for 15 minutes at $25^{\circ} \mathrm{C}$ and the reaction was started with the addition of SANA $20 \mu$ l substrate for 15 minutes on 96-well microplate (NUNC). Extracts and substrate solutions without enzymes are used as control. The absorbance was measured at $401 \mathrm{~nm}$ using a microplate reader. The inhibitory effect of the sample on antielastase activity was calculated as:

Percent Inhibition $(\%)=[(\mathrm{A}-\mathrm{B}) / \mathrm{A}] \mathrm{x} 100 \%$

$\mathrm{A}=$ absorbance control

$\mathrm{B}=$ absorbance sample

After obtaining the percentage of inhibition of each concentration, then the equation $y=b x+a$ was determined by calculating a linear regression curve where $\mathrm{x}$ is the concentration $(\mu \mathrm{g} / \mathrm{mL})$ and $\mathrm{y}$ is the percentage of inhibition (\%). Anti-elastase activity is expressed by $50 \%$ Inhibition Concentration (IC50), which is a sample concentration that can reduce enzyme elastase by $50 \%$. Myricetine was used as positive control.

\section{Antioxidant assay}

\section{DPPH assay}

DPPH free radical scavenging activities of tested extracts were determined based on a protocol modified from Bobo-Garcia, et al. A total of $0.3 \mathrm{mM}$ DPPH solution in absolute methanol was available. Samples with different concentrations in absolute methanol were evenly mixed with methanol DPPH solution to purchase a total of 200 $\mu \mathrm{L}$. After a $30 \mathrm{~min}$ incubation period in room temperature and the dark condition, the absorbance was detected at $517 \mathrm{~nm}$ by using the microplate reader. Quercetin was used as the positive control.

\section{IC50 antioxidant}

IC50 values were calculated based on the presentation of inhibition of DPPH radicals from each concentration of the sample solution with the formula:

$\%$ inhibition $=($ Absorbance sample $/$ Absorbance control $) \times 100 \%$

After obtaining the percentage of inhibition of each concentration, then the equation $y=b x+a$ was determined by calculating a linear regression curve where $\mathrm{x}$ is the concentration $(\mu \mathrm{g} / \mathrm{mL})$ and $\mathrm{y}$ is the percentage of inhibition (\%). Antioxidant activity is expressed by $50 \%$ Inhibition Concentration (IC50), which is a sample concentration that can reduce DPPH radical by $50 \%$.

\section{FRAP assay}

The FRAP radical method (Tomasina, et all) was a little modified in order to estimate the antioxidant effect of the samples. The FRAP reagent was ready freshly by mixing $10 \mathrm{~mL}$ of acetate buffer $300 \mathrm{mM}, 1$ $\mathrm{mL}$ of ferric chloride hexahydrate $20 \mathrm{mM}$ dissolved in distilled water, and $1 \mathrm{~mL}$ of 2,4,6-Tris(2-pyridyl)-s-triazine (TPTZ) $10 \mathrm{mM}$ dissolved in $\mathrm{HCl} 40 \mathrm{mM}$. $20 \mu \mathrm{L}$ sample were mixed with $280 \mu \mathrm{L}$ FRAP reagent then incubate for $30 \mathrm{~min}$ at $37^{\circ} \mathrm{C}$. The absorbance was measured at 593 $\mathrm{nm}$ with microplate reader.

\section{Total phenolic content (TPC) assay}

An amount of $20 \mu \mathrm{l}$ of methanol extract was added $100 \mu \mathrm{l}$ of FCR solution shaken for 60 seconds in a 96-well microplate (NUNC). Incubated at room temperature for 5 minutes and then added $80 \mu \mathrm{l}$ sodium carbonate solution. Shake again for 1 minute and incubate at room temperature for 2 hours. Uptake was measured on a microplate reader at $720 \mathrm{~nm}$. Control solution is made in the same way replaces the extract with distilled water. Calculation of total polyphenol content by means of a conversion on the calibration curve of gallic acid solution $4-24 \mu \mathrm{g} / \mathrm{mL}$.

\section{Total flavonoid content (TFC) assay}

A total of $20 \mu \mathrm{l}$ of methanol extract was added $20 \mu \mathrm{L}$ of aluminium chloride solution and $20 \mu \mathrm{L}$ of sodium acetate solution and $180 \mu \mathrm{L}$ of distilled water in 96-NUNC well microplate. The mixture was incubated at room temperature for 30 minutes and measured the absorption with microplate reader at $415 \mathrm{~nm}$. Calibration solution curves used quercetin in methanol $(4,6,8,10,12$, and $14 \mu \mathrm{g} / \mathrm{mL})$ were used to calculate total flavonoid contents.

\section{Statistical analysis}

All statistics analyses were achieved using SPSS 24.0 for Windows. The data was analysed by Pearson's Correlation. It is technique for investigating the relationship between two quantitative and finding association between two variables.

\section{RESULTS}

\section{Elastase assay}

Elastase is the one of the main components of extracellular matrix and thus the main to loosening of skin resulting in skin aging. The observations showed anti-elastase activities in some parts extract of Myrica javanica. Anti-elastase activity of the Myrica javanica was found to be highest in LE, SE showed the second highest anti-elastase activity while FE did not show any anti-elastase activity. Elastase inhibition results for the three extracts are below when compared with myricetine. The results are shown in (Figure 1).

\section{Antioxidant assay}

\section{DPPH assay}

DPPH radical scavenging activity was determined by using quercetin as standard $\left(R^{2}=0.9908\right)$ (Figure 2). Researces showed presence of potent DPPH radical scavenging activity in all part of Myrica javanica extracts (Table 1).

\section{FRAP assay}

The anti-oxidant ability of the Myrica javanica extracts from the three different parts to scavenge radical FRAP in vitro was analysed by microplate reader. The results are shown in Table 2.

\section{Total phenolic content (TPC) and total flavonoid content (TFC)}

TPCs of Myrica javanica extracts were determined by using gallic acid as standard $\left(\mathrm{R}^{2}=0.9964\right)$ (Figure 3$)$. It was highest in SE and lowest in fruit extract (Table 3). TFC were determined by using quercetin as standard ( $22=0.997)$ (Figure 4$). \mathrm{LE}$ showed highest TFC and FE showed lowest TFC (Table 3). 


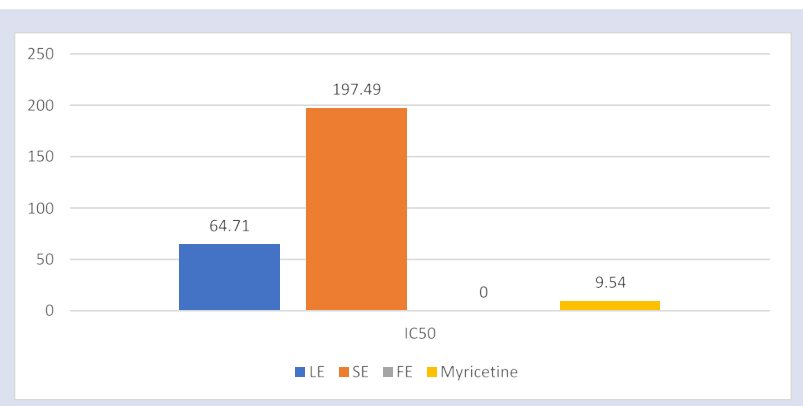

Figure 1: IC50 of some parts extract of Myrica javanica and Myricetine as positive control.

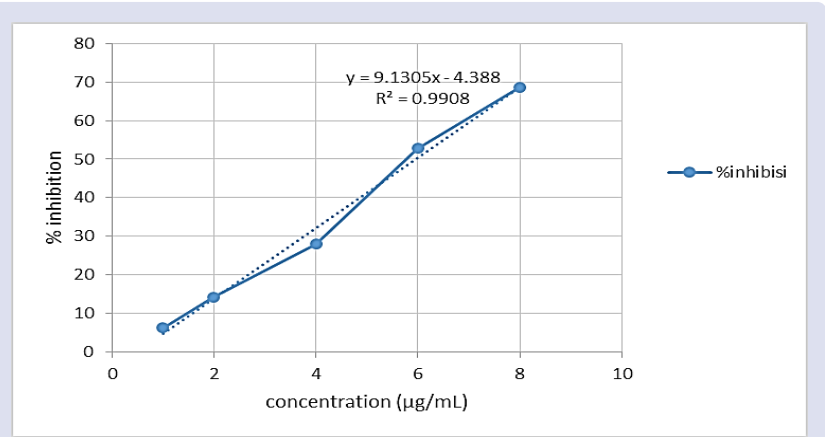

Figure 2: Calibration curve of Quercetin.

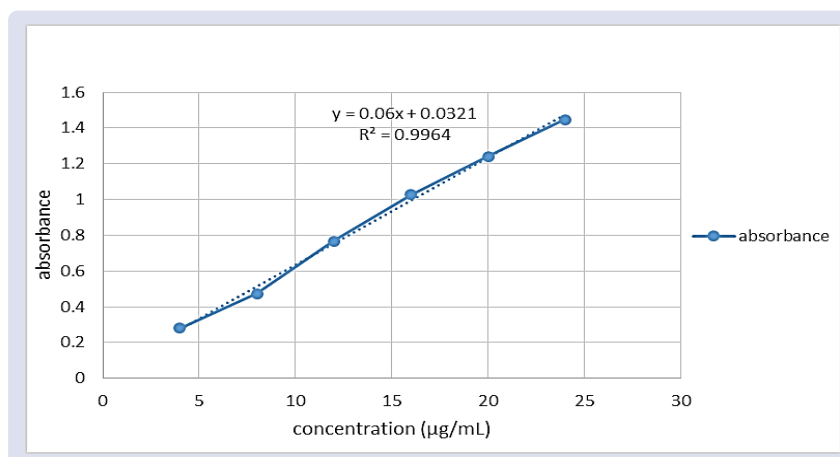

Figure 3: Calibration curve of gallic acid.

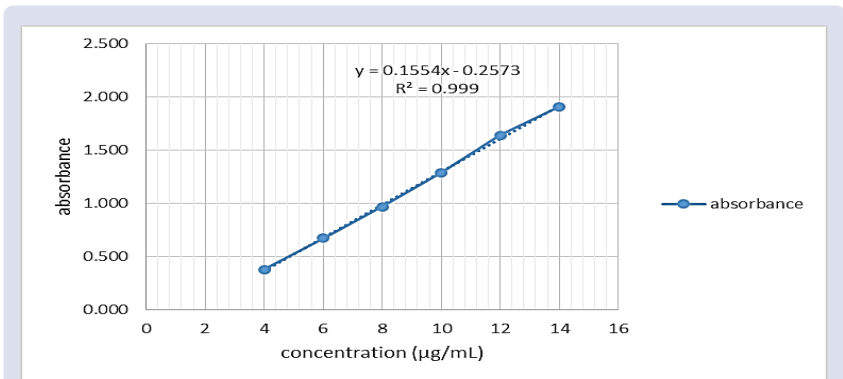

Figure 4: Calibration curve of Quercetin.

Table 1: Antioxidant Activities with DPPH Assay of Some Parts of Myrica javanica Extract.

\begin{tabular}{cccc}
\hline Sample & Equation & $\mathbf{R}^{2}$ & $\begin{array}{c}\text { IC50 DPPH } \\
(\mathbf{p p m})\end{array}$ \\
\hline Leaf Extract & $\mathrm{y}=2.2892 \mathrm{x}+0.03$ & 0.9993 & 21.83 \\
Stem Extract & $\mathrm{y}=3.3542 \mathrm{x}-4.877$ & 0.9978 & 16.36 \\
Fruit Extract & $\mathrm{y}=0.2637 \mathrm{x}+13.643$ & 0.9996 & 137.87 \\
Quercetin & $\mathrm{y}=9.1305 \mathrm{x}-4.388$ & 0.9908 & 5.96 \\
\hline
\end{tabular}

Table 2: Result FRAP Assay of Myrica javanica extracts indicated by the amounts of ferrous ion (Mol/gram).

\begin{tabular}{cc}
\hline Sample & FeEAC (Mol/gram) \\
\hline Leaves extract & 421.68 \\
Stems extract & 390.00 \\
Fruit extract & 73.04 \\
\hline
\end{tabular}

Table 3: TPC and TFC in the ethanol extracts of Myrica javanica.

\begin{tabular}{ccc}
\hline Sample & $\begin{array}{c}\text { TPC } \\
\text { (mg GAE/g Dry Weigth) }\end{array}$ & $\begin{array}{c}\text { TFC } \\
\text { (mg QE/g Dry Weigth) }\end{array}$ \\
\hline Leaf Extract & 259.40 & 15.80 \\
Stem Extract & 307.00 & 10.03 \\
Fruit Extract & 36.80 & 4.09 \\
\hline
\end{tabular}

Table 4: Pearson's Correlation value in some extracts of Myrica javanica $(n=3)$.

\begin{tabular}{ccc}
\hline & TPC & TFC \\
\hline Elastase inhibition (\%) & 0.683 & $0.990^{*}$ \\
DPPH (IC50) & $-0.992^{\star}$ & -0.850 \\
FRAP (\%) & $0.965^{\star}$ & $0.916^{*}$ \\
\hline
\end{tabular}

Note: ${ }^{*} \mathrm{r}>0.9$ has a very strong correlation

\section{DISCUSSION}

Based on the results obtained, for anti-elastase activity have a very strong correlation with the TFC values shown in Table 4. That means with the increase in TFC, the percent inhibition of elastase will be even greater. Based on Kanashiro et al. (2007), some flavonoid compounds such as quercetin, myricetin can inhibit elastase. ${ }^{11}$

The antioxidant activity (DPPH Assay) of SE (IC50 $=16.36 \mu \mathrm{g} / \mathrm{mL}$ ) and LE $($ IC50 $=21.83 \mu \mathrm{g} / \mathrm{mL})$ have strong antioxidant activity (the IC50 value $<10 \mu \mathrm{g} / \mathrm{mL})$, while FE (IC50 $=137.87 \mu \mathrm{g} / \mathrm{mL})$ has antioxidant activity that is weak (the IC50 value range from 100-250 $\mu \mathrm{g} / \mathrm{mL}$ ), if IC50 is above $250 \mu \mathrm{g} / \mathrm{mL}$ then the compound has no antioxidant activity. ${ }^{15}$

Likewise, for FRAP results in FE have the lowest percent inhibition among others. This present study is correlated with Spinola et al. (2014) that FE from another Myrica genus show weaker antioxidant activity compared to $\mathrm{LE}^{6}$, but in Li et al. (2017) study that FE of Myrica rubra have stronger antioxidant activity compared to LE and SE. ${ }^{16}$

TPC was showed a very strong relationship with DPPH and FRAP (Table 4). Due to the same principle that utilizes an electron-transfer mechanism, extract with high TPC contribute to express high DPPH scavenging activity. ${ }^{17}$

\section{CONCLUSION}

Among the test samples, anti-elastase and antioxidant activity are influenced by differences in the content of compounds in the extract. In the elastase inhibition and reduction of $\mathrm{Fe}$ ions, the compounds that play a role are the flavonoid group. As for the inhibition of free radicals are a phenolic group. Therefore, it is hoped that further research into a main compound that has the role of inhibiting the antiaging process.

\section{ACKNOWLEDGMENT}

This research was supported by Faculty of Pharmacy, Universitas Indonesia and funded by Directorate of Research and Community Engagement (PITTA B 2019), Universitas Indonesia.

\section{CONFLICTS OF INTEREST}

The authors have not declared any conflict of interest. 


\section{ABBREVIATIONS}

ROS: oxygen radical species, TPC: total phenolic content, TFC: total flavonoid content, LE: leaves extract, SE: stem extract, FE: fruit extract, DPPH: 2,2-difenil-1- pikrilhidrazil, FRAP: ferric reducing antioxidant power, TPTZ: 2,4,6-Tris(2-pyridyl)-s-triazine.

\section{REFERENCES}

1. Hooda R. Antiwrinkle Herbal Drugs - An Update. Journal of Pharmacognosy and Phytochemistry. 2015;4(4):277-81.

2. Ganceviciene R, Liakou Al, Theodoridis A, Makrantonaki E, Zouboulis CC. Skin Anti-Aging Strategies. Dermato-Endocrinology. 2012;4:3:308-19.

3. Azmi N, Hashim P, Hashim DM, Halimoon N, Majid NMN. Anti-Elastase, AntiTyrosinase and Matrix Metalloproteinase-1 Inhibitory Activity of Earthworm Extracts as Potential New Anti-Aging Agent. Asian Pacific Journal of Tropical Biomedicine. 2014;4(Suppl 1):S348-52.

4. Ndlovu G, Fouche G, Tselanyane M, Cordier W, Steenkamp V. In Vitro Determination of the Anti-Aging Potential of Four Southern African Medicinal Plants. BMC Complementary and Alternative Medicine. 2013;13:304.

5. Rawat S, Jugran A, Giri L, Bhatt ID, Rawal RS. Assessment of Antioxidant Properties in Fruits of Myrica esculenta: A PopularWild Edible Species in Indian Himalayan Region. Evidence-Based Complementary and Alternative Medicine. $2011 ; 512787(8)$.

6. Spinola V, Llorent-Martinez EJ, Gouveia S, Castilho PC. Myrica faya: A New Source of Antioxidant Phytochemicals. Journal Agricultural and Food Chemistry. 2014;62:9722-35

7. Mathiesen L, Malterud KE, Sund RB. Antioxidant Activity of Fruit Exudate and C-Methylated Dihydrochalcones from Myrica gale. Pianta Med. 1995;61:515-8.

8. Lee KK, Choi JJ, Park EJ, Choi JD. Anti-Elastase and Anti-Hyaluronidase of Phenolic Substance from Areca Catechu as A New Anti-Ageing Agent. International Journal of Cosmetic Science. 2001;23:341-6.
9. Thring T, Hili P, Naughton DP. Anti-Collagenase, Anti-Elastase and Anti-Oxidant Activities of Extracts from 21 Plants. BMC Complementary and Alternative Medicine. 2009:9:27.

10. Singh JP, Kaur A, Shevkani K, Singh N. Influence of Jambolan (Syzygium Cumini) and Xanthan Gum Incorporation on the Physicochemical, Antioxidant and Sensory Properties ff Gluten-Free Eggless Rice Muffins. International Journal of Food Science and Technology. 2015;50(5):1190-7.

11. Kanashiro A, Souza JG, Kabeya LM, Azzolini AECS, Luciano-Valim YM. Elastase Release by Stimulated Neutrophils Inhibited by Flavonoids: Importance of the Catechol Group. Zeitschrift fur Naturforschung. 2007;62c:357-61.

12. Wittenauer J, Mäckle S, Sußmann D, Schweiggert-Weisz U, Carle R. Inhibitory Effects of Polyphenols from Grape Pomace Extract on Collagenase and Elastase Activity. Fitoterapia. 2015;101:179-87.

13. Bobo-Garcia G, Davidov-Pardo G, Arroqui C Virseda P, Marin-Arroyo MR Navarro M. Intra-Laboratory Validation of Microplate Methods for Total Phenolic Content and Antioxidant Activity on Polyphenolic Extracts, and Comparison with Conventional Spectrophotometric Methods. Journal Science Food Agriculture. 2015;95:204-9

14. Tomasina F, Carabio C, Celano L, Thomsont L. Analysis of Two Methods to Evaluated Antioxidants. Biochemistry and Molecular Biology Education. 2012;40(4):266-70

15. Phongpaichit S, Nikom J, Rungjindamai N, Sakayaroj J, Hutadilok-Towatana N Rukachaisirikul V, Kirtikara K. Biological Activities of Extracts from Endophytic Fungi Isolated from Garcinia Plants. FEMS Immunol Med Microbiol. $2007 ; 51 ; 517-25$

16. Li Z, ShiW, Cheng L, Pan S, Wang C. Screening of The Phenolic Profile and Their Antioxidative Activities of Methanol Extracts of Myrica rubra Fruits, Leaves and Bark. Journal of Food Measurement and Characterization. 2017;12(1):128-34

17. Karadag A, Ozcelik B, Saner S. Review of Methods to Determine Antioxidant Capacities. Food Anal Method. 2009;2:41-60.

\section{GRAPHICAL ABSTRACT}

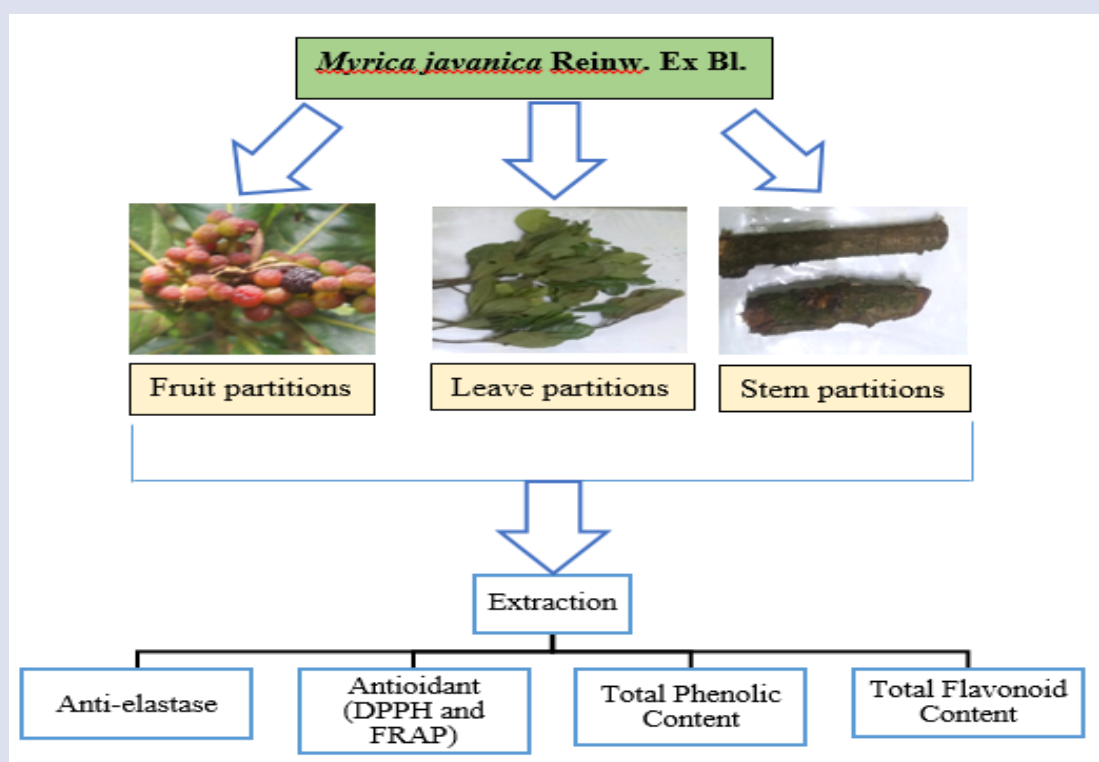

\section{SUMMARY}

- IC50 anti-elastase on leaves extract (LE), stems extract (SE), and fruits extract (FE) respectively showed 64.71 ppm, 197.49 ppm, and no activity. The anti-elastase result of three extracts are lower if compared with Myricetine (9.54 ppm).

- SE showed highest DPPH and TPC value (IC50=16.36 $\mathrm{gg} / \mathrm{mL} ; 307.00 \mathrm{mgGAE} / \mathrm{g}$ dry weight) and LE showed highest FRAP and TFC value (421.68 Mol/gram; $15.80 \mathrm{mgQE} / \mathrm{g}$ dry weight). 


\section{ABOUT AUTHORS}

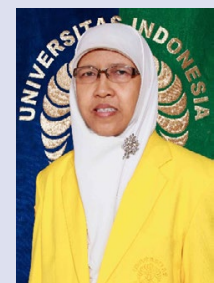

Berna Elya is Professor and Lecturer at the Faculty of Pharmacy, University of Indonesia. Develops work in the area of Pharmacognosy, Phytochemistry, and Natural Materials Chemistry.

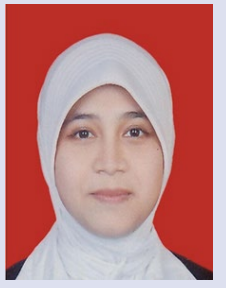

Varda Arianti is a magister student at the Faculty of Pharmacy, University of Indonesia. Her magister research focused on the Myrica javanica Reinw. ex BI. plant.

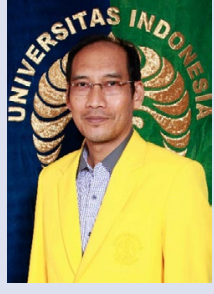

Iskandarsyah is Lecturer and Researcher at the Faculty of Pharmacy, University of Indonesia. His expertise in the area of Pharmaceutical Technology.

Cite this article: Arianti V, Elya B, Iskandarsyah. Anti-Elastase, Antioxidant, Total Phenolic and Total Flavonoid Content of Wuru Ketek (Myrica javanica Reinw. ex BI.) from Tangkuban Perahu, West Java - Indonesia. Pharmacog J. 2020;12(2):293-7. 